\title{
Physiological and biochemical aspects of flower development and senescence in Nicotiana plumbaginifolia Viv.
}

\author{
Shaziya Nisar, Inayatullah Tahir*, Syed Sabhi Ahmad, Riyaz Ahmad Dar \\ Department of Botany \\ University of Kashmir \\ Srinagar-190006 India
}

\begin{abstract}
Healthy buds of Nicotiana plumbaginifolia growing in the Kashmir University Botanic Garden were selected for the present study. Flower development and senescence was divided into seven stages, viz., tight bud stage (I), mature bud stage (II), pencil stage (III), partially open stage (IV), open stage (V), partially senescent stage (VI) and senescent stage (VII). Various physiological and biochemical changes were recorded at each stage of flower development and senescence. Floral diameter, fresh mass, dry mass and water content showed an increase up to flower opening (stage V) and thereafter a significant decrease was recorded as the flower development progressed towards senescence through stages VI and VII. An increase in $\alpha$-amino acids, total phenols and sugars was registered towards anthesis (stage V) and a decrease in these parameters was recorded with senescence. Protease activity showed a significant increase towards senescence with a concomitant decrease in soluble proteins. Based on the quantitative analysis of various biochemical parameters, the flower opening in N. plumbaginifolia seems to be accompanied by an increase in the water content, soluble proteins, $\alpha$-amino acids and phenols. A decrease in these parameters, besides an increase in protease activity induces senescence in the beautiful flowers of $N$. plumbaginifolia. Understanding flower senescence may help in improving the postharvest performance of this beautiful ornamental flower to make it a potential material for the floriculture industry.
\end{abstract}

Key words: ornamental, protease activity, proteins, senescence, sugars

\section{INTRODUCTION}

Senescence is a highly dynamic and genetically regulated programme that involves an ordered set of events at physiological and biochemical levels, including activation of hydrolytic enzymes, production of reactive oxygen species (ROS), loss of plasma membrane integrity, degradation of proteins, lipids, carbohydrates and nucleic acids (Ahmad and Tahir 2015, Rahmani et al. 2015, Ahmad and Tahir 2016a). Flower petals are considered ideal tissues for senescence studies as they are short-lived, the tissue is relatively homogenous and chemical manipulation can be applied without substantial wounding (van Doorn and Woltering 2008, Reid and Jiang 2012, Ahmad and Tahir 2016b). Flower senescence is initiated by an array of external and internal factors which initiate a series of physiological and biochemical events orchestrated by plant hormones. Ethylene has been found to be the main regulator of flower senescence in some plants (ethylene sensitive), while in others it has little or no role to play (ethylene insensitive) (van Doorn and Woltering 2008, Reid and Jiang 2012).

\footnotetext{
*Corresponding author.

Tel.: +91 9906536254

e-mail: inayatullahtahirku@gmail.com (I. Tahir).
} 
In addition to ethylene, abscisic acid, auxins, gibberellins and cytokinins have been found to play their part in the regulation of flower senescence in both ethylene sensitive and insensitive flower systems (Reid and Jiang 2012, Ahmad et al. 2013, Ahmad and Tahir 2015, Dar et al. 2015a, 2015b). A turnover in various plant growth regulators triggers senescence via a series of biochemical changes. In our previous study, we had found that flower senescence in $N$. plumbaginifolia was significantly delayed by various polyamines (supplied in the vase solution) by maintaining an increased level of soluble proteins, $\alpha$-amino acids, phenols and carbohydrates, besides preventing proteolysis (Nisar et al. 2015). The present investigation is an extension of the earlier work done to document the changes in various important physiological and biochemical parameters like floral diameter, fresh mass, dry mass, moisture content, soluble proteins, $\alpha$-amino acids, phenols, sugars and protease activity, in so far unexplored $N$. plumbaginifolia during flower development and senescence. Identification of senescence-related biochemical changes will help us to modulate this process in order to improve the postharvest life of this beautiful ornamental flower.

\section{MATERIAL AND METHODS}

\section{Plant material}

Floral buds of Nicotiana plumbaginifolia growing in the Kashmir University Botanic Garden under natural conditions, with a photoperiod of 14-16 hours and temperature ranging from $28-32^{\circ} \mathrm{C}$, were selected for the present study. Flower development and senescence was divided into seven stages (stage I-VII). These stages were designated as tight bud stage (I), mature bud stage (II), pencil stage (III), partially open stage (IV), open stage (V), partially senescent stage (VI) and senescent stage (VII)
(Fig. 1). Visible changes were recorded throughout flower development and senescence.

\section{Determination of fresh \& dry mass, water content and floral diameter}

Ten fresh flowers were used for the determination of fresh mass at each stage. The flowers were then kept in paper bags and oven-dried at $70^{\circ} \mathrm{C}$ for $48 \mathrm{~h}$. The material was put in a desiccator for $24 \mathrm{~h}$ before recording the dry mass. Water content was determined as the difference between fresh and dry mass. Flower diameter was recorded as the mean of two perpendicular measurements across the flower.

\section{Fixation of plant material}

One gram of finely chopped petal tissue was fixed in hot $80 \%$ ethanol in triplicate. The material was macerated in a glass pestle and mortar and centrifuged at $4000 \times \mathrm{g}$ for 20 minutes. The supernatants were pooled and made up to volume. A suitable aliquot of the supernatant was used for the determination of $\alpha$-amino acids, total phenols and sugar fractions.

\section{$\alpha$-Amino acid content}

$\alpha$-Amino acids were estimated by the method of Rosen (1957). A suitable volume of aliquot from the alcohol-soluble fraction of the tissue extract was made up to $1 \mathrm{ml}$ with distilled water, and $0.5 \mathrm{ml}$ of acetate cyanide buffer $(\mathrm{pH}=5.4)$ was added, followed by $0.5 \mathrm{ml}$ of $3 \%$ ninhydrin. The contents were heated at $100^{\circ} \mathrm{C}$ for 15 minutes, over a boiling water bath. After removing the tubes from the water bath, $5 \mathrm{ml}$ of diluent (isopropyl alcohol: water; 1:1 v/v) was added and absorbance was measured at $570 \mathrm{~nm}$.

\section{Total phenolic content}

Total phenols were estimated by the method of Swain and Hillis (1959). A suitable volume of aliquot from the alcohol-soluble fraction of the tissue extract was diluted to $7 \mathrm{ml}$ with distilled

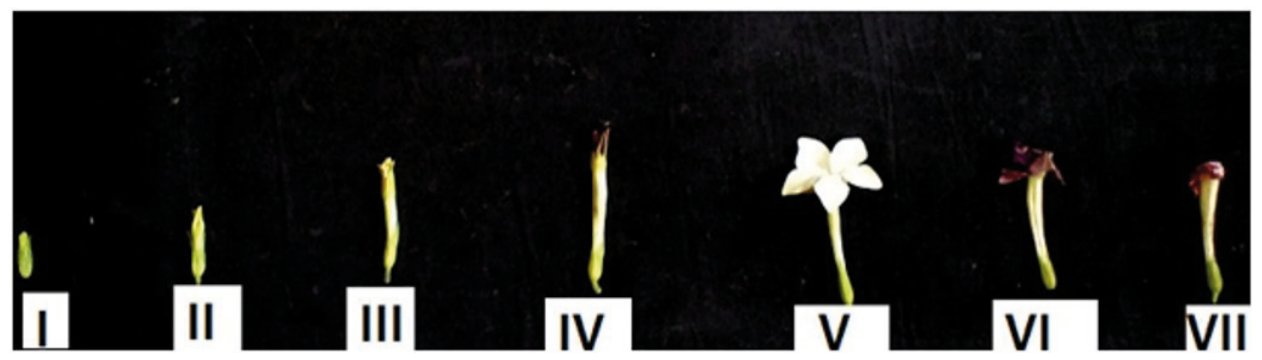

Figure 1. Various stages of flower development and senescence. Stage I - tight bud stage, Stage II - mature bud stage, Stage III - pencil stage, Stage IV - partially open stage, Stage V - open stage, Stage VI - partially senescent stage and Stage VII - senescent stage 
water, followed by the addition of $0.5 \mathrm{ml}$ of FolinDennis reagent. After 3 minutes, $1 \mathrm{ml}$ of saturated solution of sodium carbonate was added and the total volume was made up to $10 \mathrm{ml}$ with distilled water. Absorbance was measured after 30 minutes at $725 \mathrm{~nm}$.

\section{Reducing sugars}

Reducing sugars were estimated by the method of Nelson (1944). A suitable volume of aliquot from the alcohol-soluble fraction of the tissue extract was made up to $5 \mathrm{ml}$ with distilled water, followed by the addition of $1 \mathrm{ml}$ of copper reagent, prepared by mixing copper reagent $\mathrm{A}$ and $\mathrm{B}$ in the ratio of $50: 1$. The mixture was heated at $100^{\circ} \mathrm{C}$ for 20 minutes over a water bath. After cooling, $1 \mathrm{ml}$ of arsenomolybdate reagent was added and the volume was made up to $25 \mathrm{ml}$ with distilled water. Absorbance was measured at $520 \mathrm{~nm}$.

\section{Total sugars}

Total sugars were estimated after enzymatic conversion of non-reducing sugars into reducing sugars by invertase. The volume of a suitable aliquot from the alcohol-soluble fraction of the fixed material was made up to $4 \mathrm{ml}$ with distilled water, followed by the addition of $1 \mathrm{ml}$ of $0.2 \%$ invertase. A drop of toluene was layered on the top and the solution was incubated overnight at $25^{\circ} \mathrm{C}$. Total sugars were then estimated by the method of Nelson (1944).

\section{Non-reducing sugars}

Non-reducing sugars were calculated as the difference between total and reducing sugars.

\section{Estimation of proteins and protease activity}

For the estimation of proteins, $1 \mathrm{~g}$ petal tissue was homogenized in $5 \mathrm{ml}$ of $5 \%$ sodium sulphite $(\mathrm{w} / \mathrm{v})$ and $0.1 \mathrm{~g}$ of polyvinyl pyrrolidone (PVP), and centrifuged at $4000 \times \mathrm{g}$ for 20 minutes in a refrigerated centrifuge at $4^{\circ} \mathrm{C}$. Proteins were precipitated from a suitable volume of supernatant with an equal volume of $20 \%$ trichloroacetic acid (TCA) and centrifuged at $2000 \times \mathrm{g}$ for 15 minutes. The pellet was redissolved in $4 \mathrm{ml}$ of $0.1 \mathrm{~N} \mathrm{NaOH}$ and the protein content was estimated from a suitable aliquot by the method of Lowry et al. (1951).

For the estimation of protease activity, $1 \mathrm{~g}$ of pre-chilled petal tissue was homogenized in $15 \mathrm{ml}$ of chilled $0.1 \mathrm{M}$ phosphate buffer $(\mathrm{pH}$ 6.5) in a pre-cooled glass pestle and mortar. Protease activity was estimated by a modification of the method described by Tayyab and Qamar (1992). One millilitre of enzyme extract was mixed with $1 \mathrm{ml}$ of reaction mixture $(0.1 \%$ BSA dissolved in $0.1 \mathrm{M}$ phosphate buffer, $\mathrm{pH}$ 6.5). Enzyme activity was expressed as micro gram tyrosine equivalents liberated per mg protein ( $\mu \mathrm{g}$ tyrosine $\mathrm{mg}^{-1}$ protein).

\section{Scanning electron microscopic studies}

For scanning electron microscopy, the specimens were dried using a simple air-drying technique. The samples were allowed to dry slowly at room temperature. After complete air-drying, samples were kept in a desiccator for $24 \mathrm{~h}$. The petal tissue was coated with gold and loaded onto the plate of the scanning electron microscope (Model Hitachi $\mathrm{S} 3000 \mathrm{H})$. A constant voltage of $5 \mathrm{kV}$ was maintained during the analysis of the petal tissue.

\section{Statistical analysis}

The values given in the figures represent the mean of ten $(n=10)$ independent replicates. The experiment was performed twice for reproducibility of the results and the data presented in the paper is the mean value of the two repetitions. Standard deviation was computed for the data. LSD was computed at $p=0.05$ using SPSS 16 software.

\section{RESULTS AND DISCUSSION}

The present study provides an insight into various physiological and biochemical changes associated with flower development and senescence in $N$. plumbaginifolia. These changes are pivotal for the developmental shift from bud to senescence of the flowers in N. plumbaginifolia. The green floral buds of $N$. plumbaginifolia open into beautiful pink and white flowers. The flowers remain open for three days on average under natural conditions, after which they show signs of senescence like loss of petal turgidity and out rolling of the corolla. Towards the peak of senescence, the petals wilt and the ovary size increases considerably. A significant increase in floral diameter from 0.2 to $4.9 \mathrm{~cm}$ was registered from bud (stage I) to bloom (stage IV) and thereafter a sharp decrease $(1.3 \mathrm{~cm})$ was recorded towards flower senescence (Fig. 2). Fresh mass initially showed a significant increase from bud $(0.15 \mathrm{~g})$ to bloom $(0.41 \mathrm{~g})$ and thereafter decreased sharply $(0.25 \mathrm{~g})$ towards senescence (Fig. 3). Dry mass showed an increase from 0.02 to $0.07 \mathrm{~g}$ towards flower opening and a significant decrease $(0.05 \mathrm{~g})$ with senescence. Water content registered a sharp increase from 0.13 to $0.34 \mathrm{~g}$ as the flower development progressed from bud to bloom 


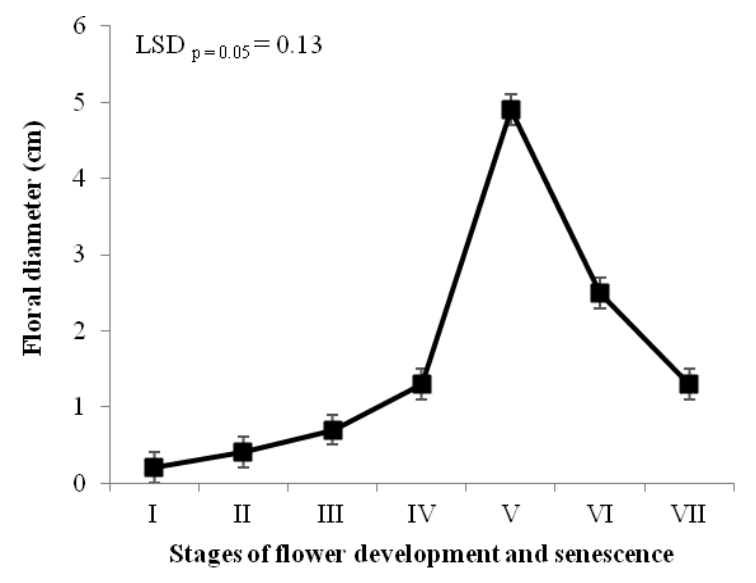

Figure 2. Changes in floral diameter during various stages of flower development and senescence

and a sharp decrease $(0.19 \mathrm{~g})$ as the flower proceeded from anthesis towards senescence. A similar pattern of changes in these parameters towards senescence has been recorded in Iris germanica, Dianthus chinensis and Consolida ajacis (Ahmad et al. 2013, Dar et al. 2014a, Ahmad and Tahir 2015). The floral diameter decreases with senescence because of the loss of tepal turgidity making the cells flaccid. Water is required for cell expansion, which is an important criterion for flower opening and maintaining the shape of flowers (Ahmad et al. 2013). The decrease in fresh and dry mass towards senescence can be attributed to the fact that during senescence flowers act as a source for ecological benefits of the plant (Zhou et al. 2005, Trivellini et al. 2011, Dar et al. 2014a, Ahmad and Tahir 2016b). The resource draining from the senescing petals helps the plant to maintain its pool of resources and reallocate them to those plant parts which are under development. The increase in water content towards flower opening is attributed to the increase in cell turgidity, which is an important criterion for flower opening (Yamada et al. 2007).

The concentration of soluble proteins showed a marginal increase from stage $\mathrm{I}\left(8.48 \mathrm{mg} \mathrm{g}^{-1}\right.$ f.m.) to stage IV (8.84 $\mathrm{mg} \mathrm{g}^{-1}$ f.m.) and thereafter a significant decrease was recorded $\left(4.64 \mathrm{mg} \mathrm{g}^{-1}\right.$ f.m.) as the flower development progressed towards senescence. This decrease in protein content was concomitant with increased protease activity with senescence, which was otherwise more or less constant up to flower opening (Fig. 4). The decrease in the soluble protein content towards senescence has been reported in some ethylenesensitive (Alstroemeria, Petunia, Dianthus) and ethylene-insensitive (Hemerocallis, Iris) flower



Figure 3. Changes in fresh mass, dry mass and water content during various stages of flower development and senescence

systems which also showed a sharp increase in the protease activity towards senescence (Ahmad and Tahir 2015, Dar et al. 2014b). Increased protein degradation because of the improved proteolytic cleavage or decreased protein biosynthesis has been found to be prerequisite for senescence in various flowers (Macnish et al. 2010, van Doorn and Woltering 2008).

During the present study, it was observed that a significant decrease in the $\alpha$-amino acid content was registered from stage I (12.10 $\mathrm{mg} \mathrm{g}^{-1}$ f.m.) to stage IV (10.36 $\mathrm{mg} \mathrm{g}^{-1} \mathrm{f} . \mathrm{m}$.) and thereafter an increase was observed towards senescence $\left(14.71 \mathrm{mg} \mathrm{g}^{-1} \mathrm{f}\right.$.m. (Tab. 1). The increase in the $\alpha$-amino acid content towards senescence could be attributed to the amino acids which are considered as the breakdown products of protein degradation due to increased protease activity (Ahmad et al. 2013, Dar et al. 2015a). An increase in the $\alpha$-amino acid content

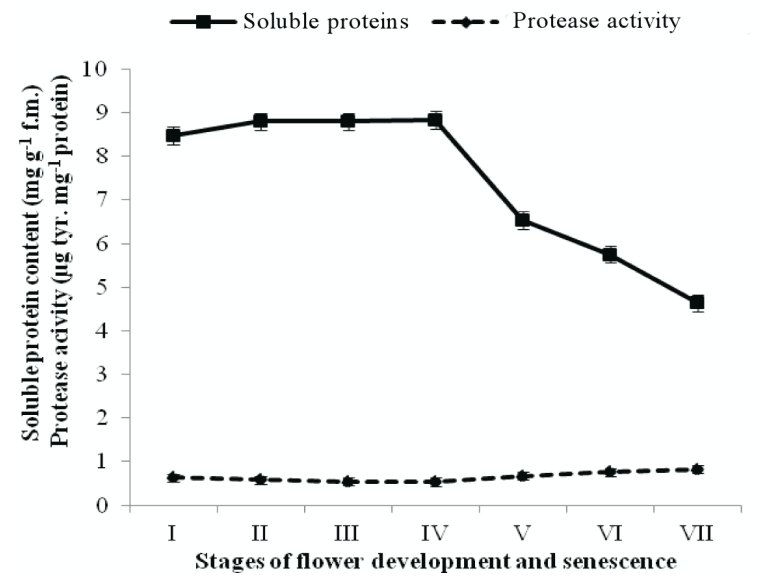

Figure 4. Changes in soluble proteins and protease activity during various stages of flower development and senescence 
Table 1. Changes in $\alpha$-amino acids, total phenols, total sugars, reducing sugars and non-reducing sugars during flower development and senescence in Nicotiana plumbaginifolia

\begin{tabular}{|c|c|c|c|c|c|c|c|}
\hline Stage I* & Stage II & Stage III & Stage IV & Stage V & Stage VI & Stage VII & $\operatorname{LSD}_{p=0.05}$ \\
\hline \multicolumn{8}{|c|}{$\alpha$-amino acids (mg g-1 f.m.) } \\
\hline $12.10 \pm 1.87$ & $11.33 \pm 2.45$ & $10.93 \pm 2.10$ & $10.36 \pm 1.63$ & $11.97 \pm 0.93$ & $11.06 \pm 2.45$ & $14.71 \pm 0.23$ & 0.23 \\
\hline \multicolumn{8}{|c|}{ Total phenols (mg g-1 f.m.) } \\
\hline $4.79 \pm 0.66$ & $5.67 \pm 0.66$ & $6.82 \pm 0.37$ & $7.19 \pm 1.21$ & $6.16 \pm 0.21$ & $5.16 \pm 0.18$ & $4.26 \pm 0.21$ & 0.14 \\
\hline \multicolumn{8}{|c|}{ Total sugars ( $\mathrm{mg} \mathrm{g}^{-1}$ f.m.) } \\
\hline $40.02 \pm 1.48$ & $41.50 \pm 0.00$ & $47.43 \pm 0.00$ & $53.36 \pm 0.00$ & $50.40 \pm 0.00$ & $19.27 \pm 2.41$ & $16.31 \pm 1.48$ & 0.76 \\
\hline \multicolumn{8}{|c|}{ Reducing sugars ( $\mathrm{mg} \mathrm{g}^{-1}$ f.m.) } \\
\hline $26.03 \pm 2.96$ & $26.30 \pm 2.96$ & $28.15 \pm 2.41$ & $29.18 \pm 0.00$ & $28.09 \pm 2.96$ & $12.40 \pm 4.44$ & $12.15 \pm 2.96$ & 0.59 \\
\hline \multicolumn{8}{|c|}{ Non-reducing sugars ( $\mathrm{mg} \mathrm{g}^{-1}$ f.m.) } \\
\hline $13.99 \pm 4.44$ & $15.20 \pm 1.48$ & $19.28 \pm 2.41$ & $24.18 \pm 1.48$ & $22.31 \pm 2.96$ & $6.87 \pm 4.44$ & $4.16 \pm 2.96$ & 0.16 \\
\hline
\end{tabular}

*Note: Stage I - tight bud stage, Stage II - mature bud stage, Stage III - pencil stage, Stage IV - partially open stage, Stage V - open stage, Stage VI - partially senescent stage, Stage VII - senescent stage

towardssenescencehasbeen reportedinsomeflowers like Hemerocallis and Dianthus (Bieleski 1993, Dar et al. 2014b). Total phenolic content initially showed an increase as the flower development progressed from stage I (4.79 $\mathrm{mg} \mathrm{g}^{-1}$ f.m.) to IV (7.19 $\mathrm{mg} \mathrm{g}^{-1}$ f.m.) but continued to decrease thereafter towards the peak of senescence ( $4.26 \mathrm{mg} \mathrm{g}^{-1}$ f.m.) (Tab. 1). Phenols are normally synthesized in plants to cope with stress and scavenge free radicals to keep the cells under homeostatic balance (Cavaiuolo et al. 2013, Ahmad and Tahir 2016d). A decrease in the phenolic content indicates that the flower is under oxidative stress, which may lead to the programmed cell death (Mittler et al. 2004, Ahmad and Tahir 2016a, Ahmad and Tahir 2016d). The soluble sugar content of tissue revealed a significant increase in the various sugar fractions (total, reducing and non-reducing) from bud to the open flower stage and thereafter a sharp decrease was registered in the sugar fractions. Total sugars increased from $40.02 \mathrm{mg} \mathrm{g}^{-1}$ f.m. to $53.36 \mathrm{mg} \mathrm{g}^{-1} \mathrm{f} . \mathrm{m}$. as the flower progressed from stage I to stage IV, while a sharp decrease $\left(16.31 \mathrm{mg} \mathrm{g}^{-1}\right.$ f.m.) was recorded towards the fully senescent stage VII. Reducing sugar

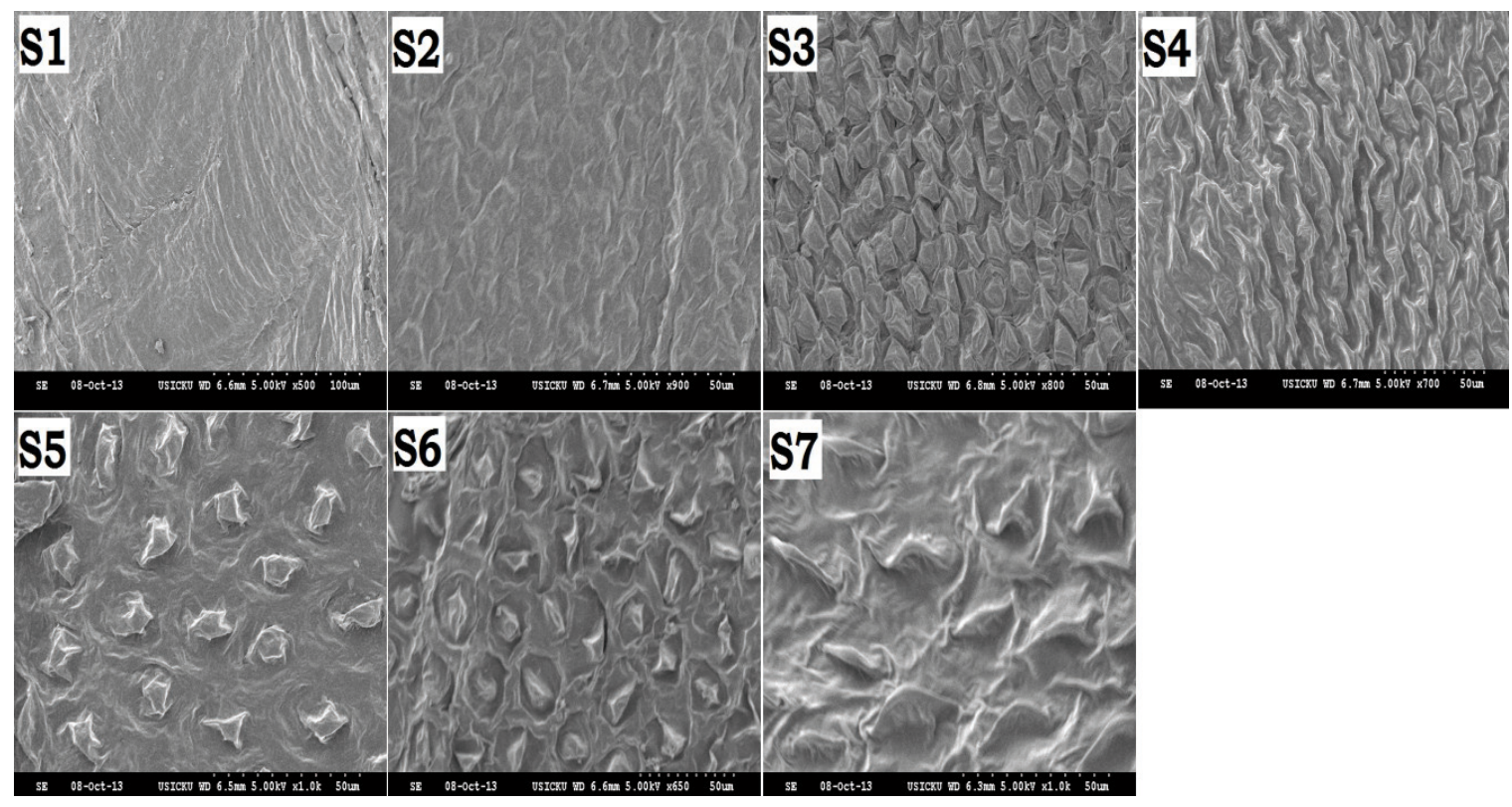

Figure 5. Scanning electron micrographs of the various stages of flower development and senescence in $N$. plumbaginifolia

Note: S1 - Stage I (tight bud stage), S2 - Stage II (mature bud stage), S3 - Stage III (pencil stage), S4 - Stage IV (partially open stage), S5 - Stage V (open stage), S6 - Stage VI (partially senescent stage), S7 - Stage VII (senescent stage). The photographs are at $400 \times$ magnification. Note the turgidity of cells at stage IV (one day before anthesis) and cellular disorganization during senescence in stages VI and VII 
content also showed a sharp decrease from the open flower stage ( $28.09 \mathrm{mg} \mathrm{g}^{-1}$ f.m.) to senescence (12.15 $\mathrm{mg} \mathrm{g}^{-1}$ f.m.), while the decrease in non-reducing sugars was more pronounced, from $22.31 \mathrm{mg} \mathrm{g}^{-1}$ f.m. in the open flower stage to $4.16 \mathrm{mg} \mathrm{g}^{-1} \mathrm{f} . \mathrm{m}$. in the completely senescent stage (Tab. 1). Sugars act as respiratory substrates and the rate of respiration increases towards senescence, hence the decline in the carbohydrate level was observed during the present investigation (Dar et al. 2015a, Ahmad and Tahir 2016c). Until late in the flower development, sugar metabolism remains active in the tepal tissues to remobilize the macromolecules back to the developing parts of the plant in the form of sucrose (van Doorn and Woltering 2008, Trivellini et al. 2011). The metabolism or abundance/lack of sugars in the cells may generate an endogenous signal that initiates senescence (Dar et al. 2014a).

The scanning electron microscopic (SEM) studies of the petal tissues revealed clear changes in the cellular architecture at various stages of flower development and senescence. The study revealed that the cells maintained their integrity and gained turgor as the flower development progressed towards stage IV, i.e. one day before anthesis. The cellular architecture starts to deteriorate even before the visible symptoms of senescence appear on the floral petals. The petal turgidity starts to diminish when the flower still appears to be fresh and open (Fig. 5). SEM studies reveal that the cells lose their integrity and the plasma membrane shrinks and gets detached from the middle lamella, leaving behind various intercellular spaces. This reduction in the size of cytoplasm results in cell lysis by the rupture of tonoplast, besides the activation of phospholipase during the onset of senescence (Smith et al. 1992). Loss of membrane integrity and increase in the intercellular spaces have been reported earlier to be the initial ultrastructural changes during the onset of flower senescence in various flowers like Dianthus chinensis and D. caryophyllus (Smith et al. 1992, Dar et al. 2014b).

During the present study, it was evident that protein turnover (degradation and synthesis) plays an important role in the flower development and senescence of $N$. plumbaginifolia. Flower senescence is initiated by protein degradation and the loss of membrane integrity and the decrease in carbohydrate content further augments the process of flower senescence. Investigations involving qualitative analyses of proteins may be helpful in unravelling the mechanism of senescence at the proteomic level. Furthermore, the role of sugars as signalling molecules, besides being a respiratory substrate, can be documented.

\section{CONCLUSIONS}

1. Flower opening is preceded by an increase in the floral diameter and water content, reflecting the maintenance of increased turgor with flower opening.

2. Flower anthesis is marked by increased levels of soluble proteins, $\alpha$-amino acids and phenols, and a significant decrease in these parameters, with a concomitant increase in the protease activity, towards senescence.

3. Flower senescence has been found to be accompanied by a decrease in the respiratory substrate (sugars) in the petal tissues.

4. Cellular architecture deteriorates towards the onset of senescence as is reflected by SEM studies.

\section{FUNDING}

Syed Sabhi Ahmad thanks University Grants Commission for providing SRF under UGC (BSRJRF) scheme.

\section{AUTHOR CONTRIBUTIONS}

S.N. carried out the experimental work along with S.S.A. and R.A.D. I.T. helped in designing the experiment, supervised the laboratory work, took the photographs and edited the manuscript; S.S.A. and S.N. contributed to manuscript writing and S.S.A. performed the statistical analysis of the data.

\section{CONFLICT OF INTEREST}

Authors declare no conflict of interest.

\section{REFERENCES}

Ahmad S.S., Tahir I., 2015. Storage protocol for improving the postharvest performance in cut scapes of Iris versicolor. Acta Hort. 1060: 71-79.

Ahmad S.S., TAhir I., 2016a. Putrescine and jasmonates outplay conventional growth regulators in improving postharvest performance of Iris germanica L. cut scapes. Proc. Natl. Acad. Sci., India Sec. B: Biol. Sci. (online) doi: 10.1007/s40011-016-0767-2.

Ahmad S.S., TAhiR I., 2016b. Increased oxidative stress, lipid peroxidation and protein degradation trigger senescence in Iris versicolor L. flowers. Physiol. Mol. Biol. Plants 24(4): 507-514. 
Ahmad S.S., TAhiR I., 2016c. How and why of flower senescence: understanding from models to ornamentals. Indian J. Plant Physiol. 21(4): 446-456.

Ahmad S.S., Tahir I., 2016d. Regulatory role of phenols in flower development and senescence in the genus Iris. Indian J. Plant Physiol. 22(1): 135-140.

Ahmad S.S., Tahir I., Shahri W., 2013. Effect of different storage treatments on physiology and postharvest performance in cut scapes of three Iris species. J. Agric. Sci. Technol. 15: 323-331.

BiELESKi R.L., 1993. Fructan hydrolysis drives petal expansion in the ephemeral daylily flower. Plant Physiol. 103(1): 213-219.

Cavaiuolo M., Cocetta G., Ferrante A., 2013. The antioxidants changes in ornamental flowers during development and senescence. Antioxidants 2: 132155.

DAR R.A., TAhir I., Ahmad S.S., 2014a. Sugars and sugar alcohol have their say in the regulation of flower senescence in Dianthus chinensis L. Sci. Hort. 174: 24-28.

Dar R.A., Tahir I., Ahmad S.S., 2014b. Physiological and biochemical changes associated with flower development and senescence in Dianthus chinensis. Indian J. Plant Physiol. 19: 215-221.

DAR R.A., TAhir I., Ahmad S.S., 2015a. Is the biochemical mechanism of petal senescence similar within a genus? A case study of Dianthus. Hort. Environ. Biotechnol. 56(5): 654-661.

Dar R.A., Tahir I., Ahmad S.S., 2015b. Cycloheximide efficacy varies temporally in improving postharvest performance of cool wet stored Dianthus chinensis L. cut sprays. Proc. Natl. Acad. Sci. India, Sec. B: Biol. Sci. (online) doi: 10.1007/s40011-015-0584-z.

Lowry O.H., Rosebrough N.J., FarR A.L., Randall R.J., 1951. Protein measurement with the Folin phenol reagent. J. Biol. Chem. 193: 265-275.

Macnish A.J., Jiang C.Z., Negre-Zakharov F., Reid M.S., 2010. Physiological and molecular changes during opening and senescence of Nicotiana mutabilis flowers. Plant Sci. 179(3): 267-272.

Mittler R., Vanderauwera S., Gollery M., Van Breusegem F., 2004. Reactive oxygen gene network of plants. Trends Plant Sci. 9: 490-498.
Nelson N., 1944. A photometric adaptation of the Somogyi method for the determination of glucose. J. Biol. Chem. 153: 375-380.

Nisar S., Tahir I., Ahmad S.S., 2015. Modulation of flower senescence in Nicotiana plumbaginifolia L. by polyamines. Indian J. Plant Physiol. 20: 186-190.

Rahmani I., Ahmadi N., Ghanati F., Sadeghi M., 2015. Effects of salicylic acid applied pre- or post-transport on post-harvest characteristics and antioxidant enzyme activity of gladiolus cut flower spikes. New Zeal. J. Crop Hort. 43(4): 294-305.

ReID M.S., JiAng C.Z., 2012. Postharvest biology and technology of cut flowers and potted plants. Hort. Rev. 40: 1-54.

Rosen H., 1957. A modified ninhydrin colorimetric analysis for amino acids. Arch. Biochem. Biophys. 67: 10-15.

Smith M.T., SAKs Y., Staden V.J., 1992. Ultrastructural changes in the petals of senescing flowers of Dianthus caryophyllus. Ann. Bot. 69: 277-285.

Swain T., Hillis W.E., 1959. The phenolic constituents of Prunus domestica L. - the quantitative analysis of phenolic constituents. J. Sci. Food Agric. 10: 63-68.

TAYYAB S., QAMAR S., 1992. A look into enzyme kinetics: Some introductory experiments. Biochem. Edu. 20: 116-118.

Trivellini A., Ferrante A., Vernieri P., Carmassi G., SERra G., 2011. Spatial and temporal distribution of mineral nutrients and sugars throughout the lifespan of Hibiscus rosa-sinensis L. flower. Cent. Eur. J. Biol. 6(3): 365-375.

van Doorn W.G., Woltering E.J., 2008. Physiology and molecular biology of petal senescence. J. Exp. Bot. 59: 453-480.

Yamada K., Ito M., Oyama T., NaKada M., Maesaka M., YAMAKi S., 2007. Analysis of sucrose metabolism during petal growth of cut roses. Postharv. Biol. Technol. 43(1): 174-177.

Zhou Y., Wang C., Hong G.E., Hoeberichts F.A., Visser P.B., 2005. Programmed cell death in relation to petal senescence in ornamental plants. J. Integ. Plant Biol. 47: 641650.

Received November 24, 2016; accepted March 10, 2017 